\title{
AKTIVNOSTI HRVATSKIH NARODNIH \\ KNJIŽNICA NA FACEBOOKU U UVJETIMA \\ PROLJETNOG LOCKDOWNA 2020.
}

\author{
CROATIAN PUBLIC LIBRARIES' ACTIVITIES \\ ON FACEBOOK DURING THE COVID-19 LOCKDOWN \\ IN THE SPRING OF 2020
}

\begin{abstract}
Dina Mašina Delija
Knjižnica HAZU

dinam@hazu.hr

Dunja Holcer

Narodna knjižnica i čitaonica Vlado Gotovac Sisak

dunjaholcer@gmail.com
\end{abstract}

UDK / UDC [027.022: 004.738.5]:616.2-044.372

Izvorni znanstveni rad / Original scientific paper

Primljeno / Received: 21. 1. 2021.

Prihvaćeno / Accepted: 29. 3. 2021.

\section{Sažetak}

Cilj. Cilj je rada predstaviti rezultate istraživanja načina na koji su knjižnice prihvatile i koristile društvenu mrežu Facebook kao odgovor na izvanredne prilike koje je prouzročila pandemija nove bolesti COVID-19. Hrvatska je, kao i većina europskih država, u proljeće 2020., u vrijeme izbijanja pandemije, ušla u potpuni lockdown. Sve javne službe u Hrvatskoj, uključujući i narodne knjižnice, zbog pandemije morale su zatvoriti vrata korisnicima na 38 dana, počevši od 19. ožujka 2020. godine. Hrvatske narodne knjižnice suočile su se sa značajnim promjenama u svojem poslovanju jer su tradicionalne knjižnične službe morale u kratkom vremenu transformirati u virtualno okruženje, stvarajući i dijeleći raznolike digitalne sadržaje na Facebooku, često i na dnevnoj bazi.

Pristup/metodologija/dizajn. Rad istražuje aktivnosti narodnih knjižnica na $\mathrm{Fa}$ cebooku, kojima su knjižnice nastavile služiti zajednici tijekom lockdowna. Prikazano istraživanje utemeljeno je na analizi objava narodnih knjižnica na Facebook stranicama.

Vjesnik bibliotekara Hrvatske 64, 1(2021), 95-110 ISSN 0507-1925 
Provedeno je tijekom srpnja 2020. godine na 208 hrvatskih narodnih knjižnica, tj. na uzorku od 146 knjižnica koje su u istraživačkom razdoblju imale Facebook stranicu.

Rezultati. Rezultati istraživanja pokazali su da su hrvatske narodne knjižnice uspješno odgovorile na izazove u novoj, dotad nepoznatoj situaciji, pokazujući da su sposobne brzo se prilagoditi i na odgovarajući način koristiti digitalne tehnologije. Knjižnice su razvile inovativne prakse, postajući sve kreativnije. Rezultat je bio pregršt sadržaja, na Facebooku, ali i na drugim društvenim mrežama, namijenjenog najširoj publici, od radionica za djecu i odrasle, prenošenja uživo online događanja, do organizacije virtualnih izložbi i prikupljanja relevantnih izvora informacija za istraživanje i učenje. Odaziv javnosti, odnosno uključivanje zajednice, bio je veći od očekivanog, uključujući slijeđenje, komentiranje i dijeljenje digitalnog sadržaja, kreiranog ili podijeljenog od strane narodnih knjižnica. Još jedan od učinaka izazvanog krizom bilo je ubrzano omogućavanje novih digitalnih usluga narodnih knjižnica, primjerice mogućnost online učlanjenja i posudba $e$-knjiga.

Originalnost/vrijednost. Ovo istraživanje prvi put na jednom mjestu donosi aktivnosti hrvatskih narodnih knjižnica na Facebooku u izvanrednim okolnostima lockdowna, a rezultati mogu potaknuti ostale knjižnice da u svoje poslovanje uvrste primjere ovdje predstavljene dobre prakse.

Ključne riječi: Facebook, hrvatske narodne knjižnice, pandemija bolesti COVID-19

\section{Abstract}

Purpose. The purpose of this paper is to present libraries' accepting and using the social networking service Facebook as a response to the extraordinary circumstances caused by the COVID-19 pandemic. Like most European countries, Croatia went into full lockdown during the COVID-19 outbreak in the spring of 2020. All public services in Croatia, including public libraries, were closed for 38 days, starting on March $19^{\text {th }}$. Croatian public libraries faced major changes as they had to transform their traditional library services into virtual ones, creating and sharing various digital content on Facebook, often on a daily basis.

Approach/methodology/design. This paper is about libraries' activities on Facebook as a way of serving communities during the lockdown. The presented research is based on the analysis of the posts created on public libraries' Facebook pages. It was conducted in July of 2020 on 208 Croatian public libraries, i.e. 146 of them that had a Facebook page during the research period.

Findings. The research shows that the Croatian public librarians have proved to live up to the challenges of new and unknown situations, demonstrating they can quickly adapt and appropriately use digital technologies. Libraries have been developing new innovative practices, becoming more and more creative. The result was handful of content on Facebook, but also on other social networks, like, workshops for children and 
adults; streamings of online events, organization of virtual exhibitions and collecting verified reference sources for research and learning. The public response was greater than expected, including following, commenting and sharing digital content created or shared by public libraries. Another impact of the crisis was the accelerated development of new digital library services, like online membership registration and e-books lending.

Originality/value. The research is the first overview of the Croatian public libraries' Facebook activities in extraordinary circumstances caused by lockdown and can encourage other libraries to implement the best practices presented in this paper.

Keywords: COVID-19 pandemic, Croatian public libraries, Facebook

\section{Uvod}

Godina 2020. unijela je mnoge promjene u osobne i profesionalne živote. Nova bolest COVID-19 u potpunosti je izmijenila svakodnevicu te je dovela do uspostave ,novog normalnog“. Širenje zaraze potaknulo je Stožer civilne zaštite na donošenje odluke o uspostavi lockdowna u ožujku iste godine. Tako je ograničen i rad knjižnica, uključujući i narodne, koje su bile primorane u potpunosti promijeniti svoje poslovanje. Knjižnice su potaknute na nove i kreativne načine komunikacije s korisnicima i javnosti općenito. Svoje su aktivnosti migrirale iz stvarnih u virtualne prostore, tj. na društvene mreže. To je za većinu knjižnica značilo drastičnu promjenu jer je u doba koje je prethodilo pandemiji mnoštvo narodnih knjižnica društvene mreže koristilo za objavu općih informacija i obavijesti. No, lockdown je potaknuo knjižničare da postanu aktivniji na društvenim mrežama, posebice Facebooku, kako bi i dalje mogli biti podrška svojim korisnicima i zajednici.

Ovaj se rad bavi isključivo narodnim knjižnicama i njihovom Facebook prisutnošću tijekom lockdowna koji je nastupio 19. ožujka i trajao do 26. travnja 2020. godine. Metodologija istraživanja bila je pregledavanje Facebook stranica knjižnica, najzastupljenije društvene mreže među hrvatskim knjižnicama. Istraživanjem provedenom u srpnju 2020. godine obuhvaćeno je 146 od ukupno 208 narodnih knjižnica u Republici Hrvatskoj, odnosno one narodne knjižnice koje su u trenutku istraživanja bile prisutne na društvenoj mreži Facebook.

Za vrijeme lockdowna narodne su knjižnice prilagodile i svoje financijske planove kako bi mogle u što većem stupnju odgovoriti na zahtjeve zajednice, te su u svoje usluge uvrstile i brojne nove pogodnosti, čime su izašle u susret svim potencijalnim skupinama korisnika. Rezultatima istraživanja iskazanima u radu daje se pregled aktivnosti hrvatskih narodnih knjižnica na Facebooku, ali se prikazuje i njihov utjecaj na korisnike i zajednicu u doba krize. Korištenje Facebooka omogućilo je veći angažman zajednice u životu narodnih knjižnica, kao i uvid u očekivanja i reakcije javnosti na kreativne projekte te nove knjižnične usluge i službe. 


\section{Hrvatske narodne knjižnice u web 2.0 okruženju}

Razvoj interneta doveo je do značajnih promjena u poslovanju knjižnica. Knjižnice novoga doba nisu više tradicionalno usmjerene na građu, nego na zadovoljavanje korisničkih informacijskih potreba i interesa. Knjižnica je centar cjeloživotnog učenja i neformalnog obrazovanja. Knjižničari moraju, uz svoje tradicionalne uloge, prihvatiti i mnoge suvremene - oni postaju medijski, marketinški i komunikacijski stručnjaci. U njihovo se obrazovanje neprestano treba ulagati kako bi se mogli nositi s brojnim promjenama i zahtjevima tehnologije. Knjižničari moraju zadovoljiti i potrebe svojih mladih korisnika koji se sve više koriste internetom i društvenim mrežama.

Narodne knjižnice u Hrvatskoj nastoje održati korak s neprestanim širenjem online sadržaja. Budući da su korisnici narodnih knjižnica u velikom broju korisnici interneta, knjižnice su upotrijebile vlastite snage kako bi omogućile svojim korisnicima pristup provjerenim online izvorima i sadržajima. U 2. izdanju IFLA-inih smjernica za narodne knjižnice posebno se ističe važnost publiciteta i promidžbe narodnih knjižnica. Nužno je da narodne knjižnice obrate pozornost obavještavanju o svojoj prisutnosti i uslugama. ${ }^{1}$ Jedan od najboljih načina za promociju usluga svakako je korištenje višestrukog potencijala i pogodnosti weba 2.0. U Dopuni IFLA-inog Manifesta navodi se kako je poželjno da knjižnice prošire svoje usluge korištenjem world wide weba i weba 2.0, uz koji se javljaju izrazi „knjižnica 2.0“ i „knjižničar 2.0“, no da pritom ne zanemare neprestani razvoj tehnologije, tj. web 3.0 i 4.0. ${ }^{2}$

Web 2.0 temelji se na društvenoj interakciji ravnopravnih sudionika. Naziv je osmislio Tim O'Reilly 2005 . godine. ${ }^{3}$ Odlike weba 2.0 jesu interaktivnost i dinamičnost, kao i to što korisnici, osim što pristupaju sadržajima, aktivno sudjeluju i u njihovu stvaranju. Termin „knjižnica 2.0“ prvi je koristio Michael Casey na svom blogu LibraryCrunch 2005. godine, ${ }^{4}$ a odnosi se na web 2.0 primijenjen u kontekstu knjižnice i upotrebu/sudjelovanje u različitim oblicima društvenog softvera. ${ }^{5}$ Knjižnica 2.0 nije ograničena zidovima, sadržaj na mreži dostupan je svima, knjiž-

\footnotetext{
IFLA-ine smjernice za narodne knjižnice / ur. Christie Koontz i Barbara Gubbin. 2. hrvatsko izd. Zagreb: Hrvatsko knjižničarsko društvo, 2011. Str. 39.

2 Dopuna IFLA-inog Manifesta. // IFLA-ine smjernice za narodne knjižnice / ur. Christie Koontz i Barbara Gubbin. 2. hrvatsko izd. Zagreb: Hrvatsko knjižničarsko društvo, 2011. Str. 119.

3 Stropnik, A. Knjižnica za nove generacije: virtualni sadržaji i usluge za mlade. Zagreb: Hrvatsko knjižničarsko društvo, 2013. Str. 75.

4 Holcer, D. Hrvatske narodne knjižnice i društvene mreže: doktorski rad. Zagreb: Filozofski fakultet, 2015. Str. 31. [citirano: 2020-12-14]. Dostupno i na: http://darhiv.ffzg.unizg.hr/5713/1/ Dunja_Holcer_Doktorski_rad.pdf.

5 Smjernice za knjižnične usluge za mladež: prerađeno izdanje Smjernica koje je 1996. objavio Stalni odbor Sekcije knjižnica za djecu i mladež / prir. Pat Muller i Ivan Chew; Web 2.0 i knjižnične usluge za mladež: uvod za knjižničare / prir. Ivan Chew. Zagreb: Hrvatsko knjižničarsko društvo, 2009. Str. 41.
} 
nica poziva na suradnju djelatnika, suradnika, korisnika i cijele zajednice, brzo se i lako prilagođava i koristi ono najbolje za pružanje usluga korisnicima. ${ }^{6}$ Knjižničar 2.0 jest računalno, informacijski i medijski pismen te se na odgovarajući način koristi svim vrstama izvora i tehnologija, također razvijajući društvene mreže uz razumijevanje društvenih medija. ${ }^{7}$ Noviji pojam, ,knjižnica 3.0“ znači knjižnicu bez granica, virtualnu nadopunu fizičkoj knjižnici. ${ }^{8}$

U Hrvatskoj je provedeno nekoliko istraživanja korištenja potencijala weba 2.0 , tj. društvenih mreža u narodnim knjižnicama. Većim se dijelom radilo o istraživanjima koja su se bavila svim vrstama knjižnica, uključujući i narodne. Sva navedena istraživanja navedena u daljnjem tekstu potvrdila su Facebook kao najzastupljeniju društvenu mrežu u hrvatskim knjižnicama. Facebook, nastao 2004. godine, isprva namijenjen samo studentima Harvarda, odavno je prestao biti isključivo mreža prijatelja. U današnje doba prepoznat je ogroman poslovni potencijal društvenih mreža općenito, a osobito Facebooka kao najpopularnijeg alata za marketing, promociju i interakciju s klijentima, obožavateljima, prijateljima i članovima. No, iako su društvene mreže jednostavno rješenje, mora se uzeti u obzir da su nestalne te da je ipak potrebno imati i službenu internetsku stranicu. Društvene mreže trebale bi biti podrška službenoj stranici, a ne obrnuto. Za društvene mreže potrebno je imati strategiju korištenja, a ponekad je za njihovo održavanje potrebno izdvojiti i dodatna financijska sredstva.

Bradley donosi nekoliko ključnih teza od kojih bi trebala polaziti svaka knjižnica koja razmišlja o prisutnosti na društvenim mrežama. Važnost originalnosti u sadržaju koji se dijeli jedna je od osnovnih premisa korištenja društvene mreže Facebook, kao i dosljedna aktivnost na korisničkom računu. ${ }^{9}$ Administratori Facebook računa trebali bi imati razvijenu strategiju njegova korištenja kako bi, uz što uspješniju primjenu, također mogli zaštiti sebe i svoju instituciju od mogućih negativnih posljedica, a u svrhu izgradnje što veće mreže i poticanja korisničkog sudjelovanja. Potrebno je odrediti i tko će od osoblja knjižnice biti zadužen za održavanje Facebook stranice. ${ }^{10}$

Jedno od prvih istraživanja odnosa knjižnica prema društvenim mrežama u Hrvatskoj provela je Pažur-Vojvodić 2009. godine. Tada su mišljenja knjižničara o tome da se knjižnice koriste Facebookom bila podijeljena. Dio struke nije bio sklon otvaranju poslovnog Facebook računa. Radilo se i o objektivnim razlozima kao što su nedostatak vremena, politika poslodavca, nesnalaženje u novim tehnologijama i nezainteresiranost korisnika. No dio knjižničara već je tada prepoznao

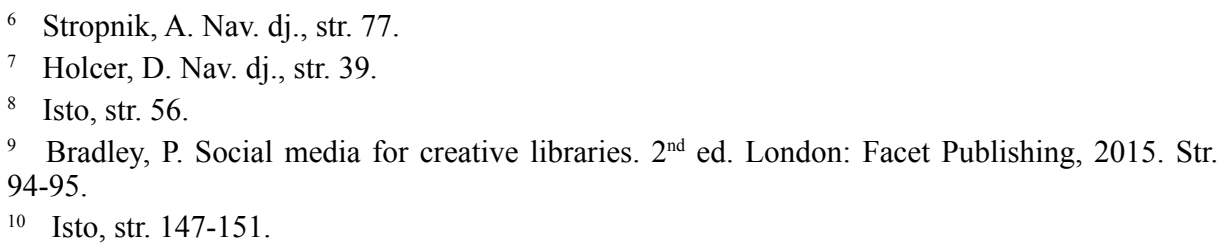


potencijal Facebooka za promociju svojih institucija i kao novo mjesto na kojem je korisnicima moguće ponuditi usluge i informacijske izvore. U trenutku provođenja spomenutog istraživanja, na Facebooku je bilo zastupljeno 13 narodnih knjižnica u Hrvatskoj. Knjižnice su Facebook prvenstveno koristile za promociju i povećanje vidljivosti u zajednici. ${ }^{11}$ Hebrang Grgić u radu iz 2012. godine donosi podatak da je 2009. godine ukupno 27 hrvatskih knjižnica koristilo Facebook. ${ }^{12}$

Benčec na temelju istraživanja provedenog u srpnju 2011. godine navodi da u trenutku provođenja istraživanja 51 narodna knjižnica u Hrvatskoj $(20$ \% od ukupnog broja knjižnica s Facebook računom u Hrvatskoj) ima otvoren Facebook račun. ${ }^{13}$ Mučnjak i Hebrang Grgić u svom istraživanju iz 2012. godine ističu da su 2011. godine upravo narodne knjižnice najzastupljenije na Facebooku te čine $54,8 \%$ od ukupnog broja knjižnica u Hrvatskoj. ${ }^{14}$ Prema istraživanju Mučnjak i Hebrang Grgić u siječnju 2012. godine na Facebooku su bile prisutne 64 hrvatske narodne knjižnice, ${ }^{15}$ dok je u srpnju iste godine broj porastao na $87 .{ }^{16}$

Pšenica, Šalamon-Cindori i Vlahov proveli su istraživanje u studenom 2012. godine. Rezultati istraživanja pokazali su da je Facebook daleko najzastupljenija društvena mreža. Twitter je koristilo $17 \%$, YouTube $15 \%$, a Pinterest tek $4 \%$ knjižnica. Istraživanje je također pokazalo kako knjižnice sadržaj ne objavljuju ažurno te da se objave većinom odnose na informacije o knjižničnim aktivnostima, novostima i zbirkama. ${ }^{17}$ Prema istraživanju koje je provela Holcer 2013.

11 Pažur Vojvodić, I. Hrvatske knjižnice na društvenoj mreži Facebook. // 13. seminar Arhivi, knjižnice, muzeji: mogućnosti suradnje u okruženju globalne informacijske infrastrukture / Mirna Willer i Sanjica Faletar Tanacković (ur.). Zagreb: Hrvatsko knjižničarsko društvo, 2010. Str. 260277.

12 Hebrang Grgić, I. Knjižnice i knjižničari na Facebooku: kako iskoristiti prednosti i izbjeći zamke? // Svezak: časopis Društva knjižničara Bilogore, Podravine i Kalničkog prigorja 15(2013), str. 11.

13 Benčec, M. Hrvatske knjižnice na društvenoj mreži Facebook: diplomski rad. Zagreb: Filozofski fakultet, 2011. Str. 13. [citirano: 2020-12-14]. Dostupno i na: http://darhiv.ffzg.unizg. hr/4243/1/1064BIBL.pdf.

14 Mučnjak, D.; I. Hebrang Grgić. Croatian and Irish public libraries on Facebook. // Qualitative and Quantitative Methods in Libraries 3(2012), 269. [citirano: 2020-12-14]. Dostupno na: http:// www.qqml.net/papers/December_2012_Issue/5QQML_Journal_2012_Hebrang_Grgic-Mucnjak_3_267-275.pdf.

15 Mučnjak, D.; I. Hebrang Grgić. Libraries and librarians on Facebook: professional vs personal involvement. // Proceedings of the IADIS international conference: Web Based Communities and Social Media 2012: Collaborative technologies 2012 / Piet Kommers, Pedro Isaias, Nik Bessis (ed.). Lisbon: International Association for Development of the Information Society, 2012. Str. 161 .

16 Hebrang Grgić, I.; D. Mučnjak. Social networking phenomenon and its use in libraries. // Croatian Journal of Education 17, 1(2015), 217-241.

17 Pšenica D.; B. Šalamon-Cindori; D. Vlahov. Novi oblici komunikacije knjižnica u online okruženju. // Slobodan pristup informacijama: 12. okrugli stol: zbornik radova. Zagreb: Hrvatsko knjižničarsko društvo, 2013. Str. 24-32. 
godine, broj narodnih knjižnica s pojavnosti na Facebooku porastao je na $98 .^{18}$ Majcen Linn u istraživanju iz rujna 2014. godine dolazi do brojke od 152 narodne knjižnice s Facebook računom (slika 1). ${ }^{19}$

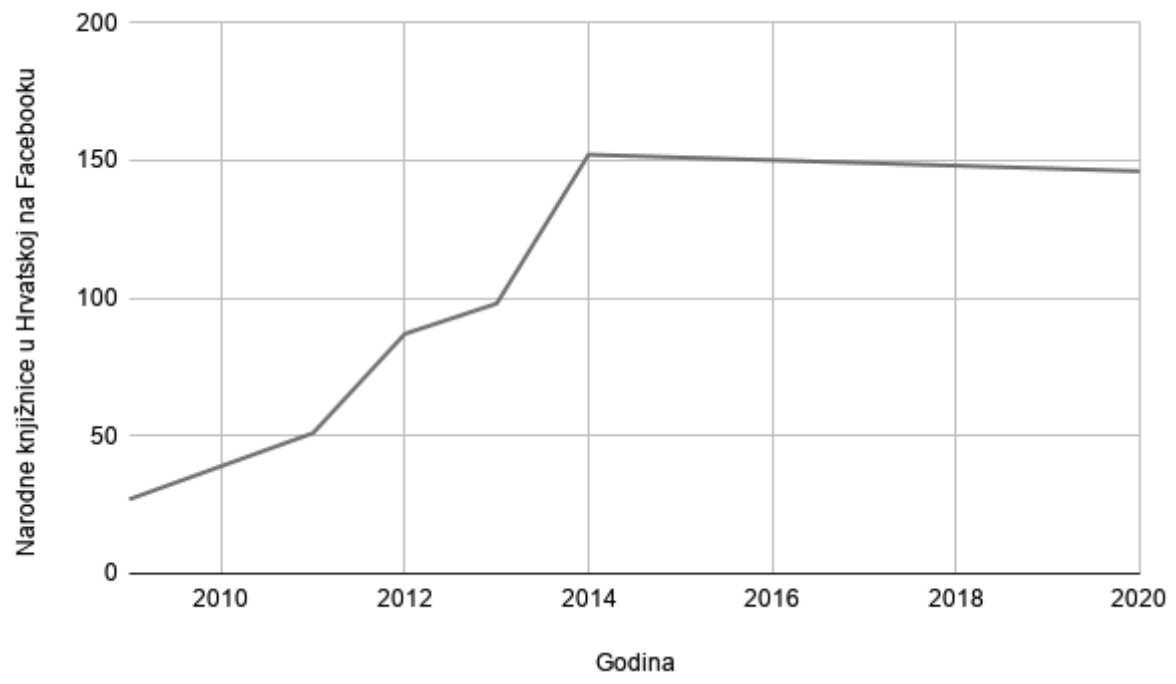

Slika 1. Broj narodnih knjižnica u Hrvatskoj prisutnih na Facebooku od 2009. do 2020.

Navedena istraživanja ističu identične probleme kao što su neažurnost u objavljivanju sadržaja i velika aktivnost malog broja knjižnica. Benčec u provedenoj analizi sadržaja objava utvrđuje da se objave narodnih knjižnica većinom (47 \%) odnose na aktivnosti u knjižnici/ustanovi. Autorica zaključuje kako hrvatskim knjižnicama nedostaje strategija, koja znači i neodržavanje profila, ${ }^{20}$ te da čak trećina sadržaja nije redovito ili uopće održavana. ${ }^{21}$ Prema istraživanju Holcer iz 2013., 56 \% svih objava objavilo je $16 \%$ knjižnica, tek 17 od 51 knjižnice imalo je potpuno neaktivnu pojavnost tijekom promatranog razdoblja. Sami sadržaji objava raznolikiji su nego u ranijim godinama. Iznenađujuć podatak tog istraživanja bio je da $70 \%$ ispitanika ne prati knjižnice na društvenim mrežama. Čak 56 \% ispitanika nije znalo koristi li knjižnica neku od društvenih mreža. ${ }^{22}$ Majcen Linn na temelju provedenog istra-

\footnotetext{
18 Holcer. Nav. dj., str. 222

19 Majcen Linn, O. Prisutnost hrvatskih knjižnica na društvenoj mreži Facebook u razdoblju od 2012.- 2014.: diplomski rad. Zagreb: Filozofski fakultet, 2014. Str. 11. [citirano: 2020-12-14]. Dostupno na: http://darhiv.ffzg.unizg.hr/id/eprint/5006/.

20 Autorica govori o profilima, iako bi ustanove trebale imati Facebook stranicu, ne profil.

21 Benčec, M. Nav. dj., str. 34-37.

22 Holcer, D. Nav. dj., str. 221-228.
} 
živanja iz 2014. zaključuje da postoji određen napredak u shvaćanju Facebooka kao alata te da dio knjižnica smatra da je to dobar način za poticanje korisnika na aktivnost. No većini knjižničara nedostaje sustavna institucijska podrška, dodatna izobrazba i poticaj na kreativnost u korištenju tog alata, što su neki od osnovnih uvjeta kako bi se u potpunosti iskoristio njegov kapacitet. ${ }^{23}$

Facebook 2019. godine broji 2,6 milijardi korisnika u svijetu, što je 60,6 \% korisnika interneta. ${ }^{24}$ Iako hrvatske knjižnice koriste i ostale društvene mreže, Facebook je i dalje najpopularnija. Godine 2020. zabilježeno je 1800000 hrvatskih korisnika Facebooka (43,85 \% stanovništva) ${ }^{25}$ a to je još uvijek najzastupljenija mreža u hrvatskim knjižnicama, uključujući i one narodne. Važno je napomenuti da sve knjižnice koje koriste Instagram i Twitter, također koriste Facebook (slika 2).

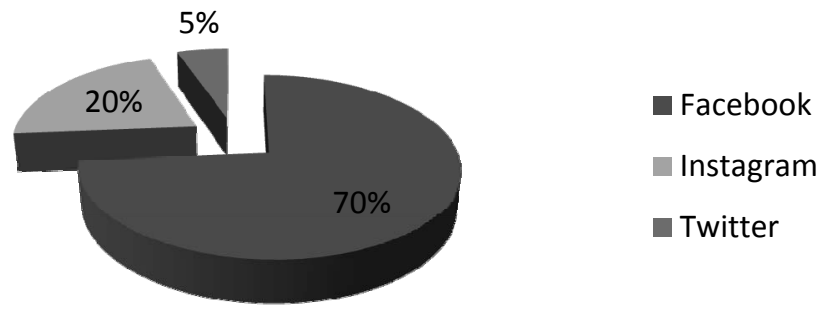

Slika 2. Narodne knjižnice u Hrvatskoj - prisutnost na društvenim mrežama 2020.

\section{Hrvatske narodne knjižnice u doba lockdowna}

Ovo istraživanje provedeno je tijekom lockdowna, tj. od 19. ožujka do 26. travnja 2020. godine, a podaci su prikupljeni tijekom srpnja 2020. U istraživanje je bilo uključeno 146 od 208 narodnih knjižnica u Hrvatskoj, odnosno knjižnice koje su u istraživačkom razdoblju imale aktivnu Facebook stranicu. Metoda istraživanja bila je sadržajna analiza knjižničnih objava na Facebooku, koje su pritom svrstane u kategorije, određene od strane autorica ovog rada. Cilj istraživanja bio je utvrditi kako su knjižnice koristile društvenu mrežu Facebook tijekom lockdowna. Istraživanje je bilo ograničeno na upotrebu ove društvene mreže jer se radi o najpopularnijoj i najkorištenijoj društvenoj mreži na svijetu, kao i u hrvatskim knjižnicama, što je i obrazloženo u prethodnom poglavlju.

23 Majcen Linn, O. Nav. dj., str. 37.

24 Summary: Facebook statistics. // Oberlo. [citirano: 2020-12-14]. Dostupno na: https://www. oberlo.com/blog/facebook-statistics\#: :text=a\%20daily\%20basis.-,Facebook\%20is $\% 20$ the $\% 20$ leading $\% 20$ social $\% 20$ platform $\% 2 \mathrm{C} \% 20$ reaching $\% 2060.6 \% 20$ percent $\% 20$ of,ad $\% 20$ revenue $\% 20$ in $\% 20$ Q1\%202020.

25 Facebook users by country 2020. // World Population Review. [citirano: 2020-12-14]. Dostupno na: https://worldpopulationreview.com/country-rankings/facebook-users-by-country. 
Prvi slučaj bolesti COVID-19 u Hrvatskoj, uzrokovan infekcijom novim koronavirusom SARS-CoV-2 dijagnosticiran je 25. veljače 2020. u Zagrebu. ${ }^{26}$ Porast broja oboljelih do ožujka 2020. potaknuo je Stožer civilne zaštite Republike Hrvatske da 19. ožujka donese Odluku o mjerama ograničavanja društvenih okupljanja, rada u trgovini, uslužnih djelatnosti i održavanja sportskih $i$ kulturnih događanja.$^{27}$ Odlukom koja je imala biti na snazi 30 dana obustavljene su sve kulturne djelatnosti, pa tako i rad narodnih knjižnica.

Knjižnice, uključujući i narodne, morale su pronaći način kako i dalje ostvarivati svoje funkcije i zadaće koje se navode u UNESCO-vu Manifestu, Smjernicama i Standardima. Kao što stoji u UNESCO-vu Manifestu za narodne knjižnice, narodne knjižnice imaju, između ostalog, ulogu obavijesnog središta koje svojim korisnicima omogućava neposredan pristup različitim vrstama znanja i informacija. ${ }^{28}$ Budući da fizički susret u knjižnici više nije bio moguć, one su nastojale odgovoriti na potrebe korisnika na jedini mogući način - organizacijom aktivnosti u virtualnom okruženju. Većina je narodnih knjižnica u razdoblju prije pandemije na svojim Facebook stranicama objavljivala opće obavijesti i informacije o radnom vremenu knjižnice. U početku pandemije narodne su knjižnice počele pružati informacije i obavijesti o pandemiji bolesti COVID-19. Knjižnice su od početka pandemije svojim korisnicima distribuirale informacije o odlukama Stožera civilne zaštite, a u novoj situaciji društvene mreže postale su jedni način održavanja konstantne prisutnosti knjižnica u zajednici.

Manifest također navodi kako se službe narodne knjižnice temelje na osiguravanju jednakosti pristupa sadržajima i uslugama knjižnice svim članovima društva, i to bez obzira na njihovu dob, rasu, spol, vjeru, nacionalnost, jezik ili društveni položaj. Za korisnike koji se iz bilo kojeg razloga ne mogu služiti redovitim uslugama i građom, potrebno je osigurati posebne službe i građu. ${ }^{29}$ Knjižnice su u tu svrhu morale osmisliti nove usluge u otežanim uvjetima, gdje postojeće službe, koje se većinom oslanjaju na fizičku prisutnost korisnika u knjižnici, nisu bile dostupne. Budući da je zbog pandemije došlo i do promjene u poslovanju, knjižnice su također počele informirati korisnike i javnost o svojim novim uslugama. Knjižnice su, da bi odgovorile na izazove nove situacije, preraspodijelile resurse

26 COVID-19 - Priopćenje prvog slučaja. // Hrvatski zavod za javno zdravstvo. [citirano: 202012-14]. Dostupno na: https://www.hzjz.hr/priopcenja-mediji/covid-19-priopcenje-prvog-slucaja/.

27 Stožer civilne zaštite Republike Hrvatske. Odluka o mjerama ograničavanja društvenih okupljanja, rada u trgovini, uslužnih djelatnosti i održavanja sportskih i kulturnih događanja. [citirano: 2020-12-14]. Dostupno na: https://civilna-zastita.gov.hr/UserDocsImages/CIVILNA\%20 ZA\%C5\%A0TITA/PDF_ZA\%20WEB/Odluka\%20-\%20mjere\%20ograni $\%$ C4\%8Davanja $\% 20$ dru\%C5\%A1tvenih\%20okupljanja,\%20rada\%20trgovina.pdf.

28 IFLA-in i UNESCO-ov Manifest za narodne knjižnice. // IFLA-ine smjernice za narodne knjižnice / ur. Christie Koontz i Barbara Gubbin. 2. hrvatsko izd. Zagreb: Hrvatsko knjižničarsko društvo, 2011. Str. 105.

29 Isto. 
kako bi nastavile služiti zajednici unatoč otežavajućim okolnostima. Primorane prijeći iz fizičkih prostora u mrežno okruženje, svojim su zalaganjem stvorile i implementirale vlastite virtualne prostore za učenje u knjižnici.

Tablica 1. Detaljan prikaz rezultata istraživanja prema vrstama objava hrvatskih narodnih knjižnica na Facebooku tijekom lockdowna 2020.

\begin{tabular}{|l|l|}
\hline Vrsta obavijesti & Broj objava \\
\hline $\begin{array}{l}\text { Dijeljenje virtualnih događanja domaćih i stranih kulturnih usta- } \\
\text { nova, udruga, skupina i sl. }\end{array}$ & 1085 \\
\hline $\begin{array}{l}\text { Razno (zanimljivosti i sl., nije moguće svrstati u neku od zadanih } \\
\text { kategorija) }\end{array}$ & 453 \\
\hline Virtualni književni i drugi susreti knjižnice i različita događanja & 411 \\
\hline Virtualne preporuke knjiga, glazbe i filmova & 272 \\
\hline Opće obavijesti (radno vrijeme, pravila ponašanja i sl.) & 264 \\
\hline $\begin{array}{l}\text { Virtualne pričaonice za djecu koje organizira knjižnica (čitanje i } \\
\text { pričanje priča) }\end{array}$ & 239 \\
\hline Informacije i obavijesti o pandemiji bolesti COVID-19 & 177 \\
\hline Virtualne izložbe & 171 \\
\hline Dijeljenje virtualnih događanja drugih knjižnica & 153 \\
\hline Virtualni kvizovi i igre knjižnice & 124 \\
\hline Informacije o novim uslugama tijekom pandemije (e-knjige i sl.) & 94 \\
\hline Virtualne radionice za djecu & 51 \\
\hline Virtualni sastanci čitateljskih klubova knjižnice & 30 \\
\hline $\begin{array}{l}\text { Objave popisa provjerenih referentnih izvora za pomoć pri is- } \\
\text { traživanju i učenju }\end{array}$ & 26 \\
\hline Virtualne radionice za odrasle & 24 \\
\hline & 3574 \\
\hline
\end{tabular}

Prikazana tablica daje pregled prema vrstama objava hrvatskih narodnih knjižnica na Facebooku tijekom lockdowna. Vrste obavijesti moguće je razvrstati u četiri kategorije. Najzastupljenija je kategorija „zabava i učenje“. Zatim slijedi kategorija „dijeljenje sadržaja“ koji su kreirale druge knjižnice te ostale institucije, skupine, udruge i pojedinci. Sljedeća, i ujedno najzastupljenija kategorija razdoblja koje je prethodilo lockdownu, jest kategorija „razne informacije“. Posljednja kategorija - „razno“ obuhvaća sve što se nije moglo uključiti u prve tri kategorije. Iz navedenog možemo zaključiti da su knjižnice napredovale od osnovnog dijeljenja informacija do preuzimanja uloge stvaratelja sadržaja za korisnike. 
Knjižničari su nastavili organizirati događanja, i to za sve uzraste. Mnoge su knjižnice započele s organiziranjem virtualnih radionica. Virtualne radionice za djecu uključivale su likovne radionice, radionice izrade igračaka, stripa, uskršnjih čestitki i ukrasa, itd. Za najmlađe korisnike knjižnice su osmislile i virtualne pričaonice za djecu, tj. čitanje i pričanje priča knjižničara.

Knjižnice su također posvetile pozornost razvijanju novih interesa i kreativnosti svojih mladih i odraslih korisnika osiguravajući različite vrste edukacija. Virtualne radionice i predavanja za odrasle obuhvaćale su razne tematike. ${ }^{30} \mathrm{Na}-$ stavilo se i održavanje sastanka čitateljskih klubova knjižnice, u online okruženju. Osim toga, održavani su i virtualni susreti s književnicima, ali i drugim osobama iz javnog života. Knjižničari su svojim korisnicima i dalje bili dostupni za preporuke knjiga, kao i ostalih zabavnih sadržaja. Objavljivane su top liste knjiga, kao i besplatne stranice i aplikacije za čitanje knjiga, preporuke radio stanica, mrežnih mjesta za slušanje glazbe i gledanje filmova.

Knjižnice su ostvarile i suradnju s drugim institucijama u kulturi kako bi zadovoljile kulturne, obrazovne i društvene interese svojih korisnika, od onih najmlađih, preko mladih i odraslih, do korisnika treće životne dobi. Domišljati i inovativni knjižničari angažirali su se i oko izrade virtualnih kvizova, igara te nagradnih natječaja za svoje korisnike i pratitelje. ${ }^{31}$ Knjižničari su priređivali i virtualne izložbe kojima su predstavljali svoj fond, kao i povijest knjige. I sami korisnici mogli su sudjelovati u izložbama slanjem vlastitih tekstova i fotografija.

Knjižnice su, osim što su stvarale sadržaje, također dijelile virtualna događanja drugih knjižnica (virtualne obilaske, slike i snimke iz drugih knjižnica), kao i ona domaćih i stranih ustanova u kulturi, udruga, skupina i sl. (kazališne predstave, emisije, zanimljivi članci, zanimljivosti iz svijeta kulture, događanja).

Za učenike, studente i sve one koji se bave istraživačkim radom, knjižničari su istražili, prikupili i objavili provjerene referentne izvore za pomoć pri istraživanju i učenju. Objave su uključivale i razne druge zanimljivosti koje nije moguće svrstati u neku od zadanih kategorija, obilježavanje raznih obljetnica (primjerice, Međunarodni dan dječje knjige 2. travnja, Dan hrvatske knjige 22. travnja, obljetnice rođenja/smrti istaknutih ličnosti i dr.), prigodne čestitke, fotografije kojima se podsjećalo na nekadašnja događanja u knjižnicama itd.

Na slici 3 prikazan je ukupan broj objava narodnih knjižnica na Facebooku $\mathrm{u}$ istraživanom razdoblju - 5 knjižnica (3\%) nije imalo niti jednu objavu, 68 knjižnica (47 \%) imalo je do 20 objava (14 \%), 41 knjižnica (28 \%) imala je od 20

30 Primjer virtulne radionice - Virtualna radionica izrade uveza knjige „Knjige imaju svoju sudbinu“. // Facebook stranica Gradske knjižnice „Ivan Goran Kovačić“ Karlovac. [citirano: 202012-14]. Dostupno na: https://www.facebook.com/KnjiznicaKarlovac/posts/3745590642149582.

31 Primjerice, Knjižnica i čitaonica Glina organizirala je nagradnu igru „Otkrij naslov svog krimića“ povodom Noći knjige 2020. [citirano: 2020-12-14]. Dostupno na: https://www.facebook. com/events/657315438162967/). 
do 39 objava (33\%), 20 knjižnica imalo je od 40 do 59 objava (27\%), dok je 12 knjižnica (8\%) imalo najveći broj objava, od 60 do 113 (26\%). Rezultati pokazuju kako je manji dio knjižnica odgovoran za većinu sadržaja, kao i u prethodnim istraživanjima opisanima u ovom radu.

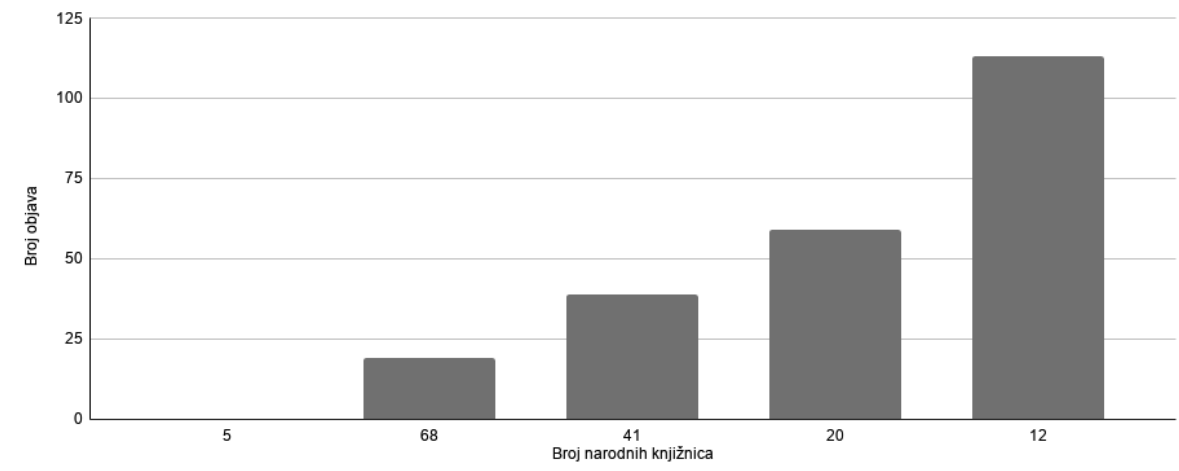

Slika 3. Broj objava narodnih knjižnica tijekom lockdowna

Prosječna dnevna objava sadržaja prikazana je na slici 4 . U prosjeku 5 knjižnica (3\%) nije imalo niti jednu objavu, 48 (33\%) ih je imalo do 10, 20 knjižnica (14 \%) imalo je od 10 do 20 objava, a njih 73 (50 \%) 30 i više.

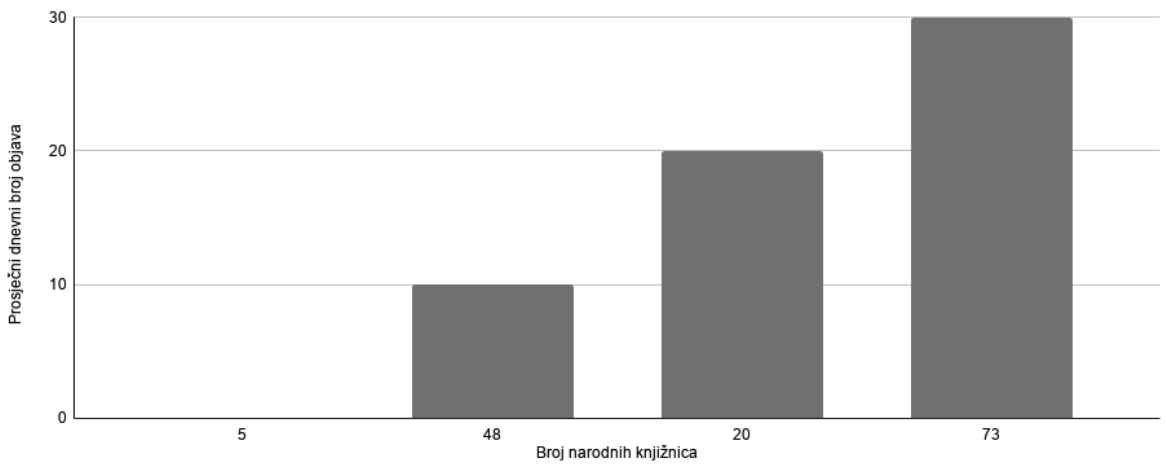

Slika 4. Prosječna dnevna objava sadržaja od strane hrvatskih narodnih knjižnica tijekom lockdowna

Važno je istaknuti da su korisnicima tijekom pandemije omogućene i neke nove usluge na kojima se ubrzano radilo kako bi što prije postale dostupne javnosti. Te usluge uključuju besplatno učlanjenje $e$-pristupnicom, besplatno obnavljanje članstva, kao i posudbu $e$-knjiga. Usluge su prvotno trebale biti predstavljene tek krajem 2020. godine, no knjižnice su odlučile ubrzano prerasporediti sredstva te učiniti usluge dostupnima ranije nego što je prvotno planirano. Članovima za- 
jednice koji ne stanuju u blizini knjižnice omogućeno je tromjesečno besplatno članstvo da bi se posudba knjiga omogućila gotovo svim građanima. U nekim su gradovima postavljene i kućice s knjigama koje su redovito nadopunjavane novim naslovima. Knjižnice svojim korisnicima nisu naplaćivale zakasninu za razdoblje u kojem nisu bile fizički dostupne.

Mnoge su knjižnice pokrenule YouTube kanal kako bi na njemu mogle objavljivati videozapise raznovrsnog sadržaja. Objavljivane videozapise knjižnice su promovirale dijeleći ih na svojim Facebook stranicama. Tako su omogućile pristup snimkama ranije održanih događanja, no i mnoštvu novonastalog sadržaja kao što su, primjerice, kreativne radionice i pričaonice za djecu i sl. Neke od knjižnica koje posjeduju digitalne repozitorije omogućile su pristup rijetkoj i jedinstvenoj građi iz svojih zbirki, dok je dio knjižnica situacija potaknula na pokretanje vlastitih digitalnih portala. Knjižnice su izrađivale i vlastite virtualne izložbe kojima su korisnicima predstavile svoju zanimljivu građu. Noć knjige je, unatoč nemogućnosti održavanja na fizičkim lokacijama, organizirana u virtualnom okruženju 23. travnja 2020. pod sloganom „S knjigom nisi izoliran!“.32 Knjižnice su tim povodom pripremile razna online događanja za korisnike.

Angažman oko virtualnoga pridonio je i pojačanom korištenju društvenih mreža koje su bile način promoviranja određenih sadržaja, kao i izvrstan alat za dobivanje povratnih informacija. Od 208 narodnih knjižnica u Hrvatskoj tijekom lockdowna njih 146 koristilo je Facebook. Tijekom 2019. godine narodne knjižnice imale su 157197 aktivnih korisnika. ${ }^{33}$ Taj je podatak zanimljiv ako za usporedbu uzmemo podatak da su u srpnju 2020. godine narodne knjižnice imale ukupno 209 981 pratitelja na Facebooku, što je $25 \%$ više nego aktivnih korisnika narodnih knjižnica tijekom 2019. godine. Korisnici su, osim praćenja i reagiranja na objave (lajkanja), na razne načine sudjelovali i u virtualnim događanjima knjižnica. Primjerice, slali su vlastite prijedloge za virtualne izložbe. ${ }^{34}$

\section{Zaključak}

Budući da je Facebook i dalje najzastupljenija društvena mreža u Hrvatskoj, logično je da se njome koristi i najveći broj hrvatskih knjižnica. Lockdown je potaknuo knjižnice na korištenje Facebooka za pružanje privlačnog, visokokvalitetnog i relevantnog sadržaja koji se može dalje dijeliti, za razliku od dotadašnje prakse knjižnica koja je uglavnom bila usmjerena na pružanje osnovnih informacija korisnicima o postojećim uslugama. Rezultati istraživanja pokazali su krea-

\footnotetext{
32 Noć knjige. [citirano: 2020-12-14]. Dostupno na: https://nocknjige.hr/

33 Statistički podaci i pokazatelji uspješnosti za 2019. [citirano: 2020-12-14] http://maticna.nsk. $\mathrm{hr} /$ statistika/preuzimanje/.

34 Moja najdraža knjiga - sudjelujte i vi!. // Facebook stranica Gradske knjižnice Solin Teatrin. [citirano: 2020-12-14]. Dostupno na: https:/www.facebook.com/events/2618937985046612/.
} 
tivnost i originalnost knjižnica u svakodnevnom stvaranju i objavi novih sadržaja kako bi održavale pozornost korisnika te pokušale, premda djelomično, zamijeniti aktivnosti koje tada nisu bile moguće. Ponuđeni su razni oblici i načini virtualne zabave i razonode.

Narodne knjižnice nisu zanemarile svoju zadaću u poticanju čitanja tijekom lockdowna te su nastavile pružati korisnicima preporuke za čitanje i organizirati virtualne sastanke čitateljskih klubova, potičući korisnike svih uzrasta na uključivanje u ta događanja. Najmlađi su mogli slušati svoje najdraže priče koje su čitali knjižničari ili vanjski suradnici narodnih knjižnica, kao i sudjelovati u raznim vrstama radionica i natječaja u organizaciji narodnih knjižnica. Promicanje informacijske pismenosti osobito je bilo zastupljeno kroz zalaganje knjižničara oko prikupljanja i dijeljenja referentnih izvora podataka za sve skupine korisnika. Studentima, znanstvenicima, kao i svima koji se bave istraživačkim radom, knjižničari u narodnim knjižnicama omogućili su uvid u vjerodostojne izvore za istraživanje i učenje. Kroz svoje su objave, i dostupnost raznih izvora, narodne knjižnice promicale i ostale vrste pismenosti koje zagovara Manifest, primjerice, digitalnu, medijsku, vizualnu i podatkovnu pismenost, kao i građansku te etičku pismenost, naglašavajući važnost informiranosti i obrazovanja.

Knjižnice su prisutnošću na društvenim mrežama nastavile ostvarivati i svoju ključnu ulogu u promicanju opće kulture. Uz organiziranje vlastitih događanja kojima se poticalo čitanje i druge aktivnosti iz područja kulture, knjižnice su dijelile obavijesti srodnih institucija, kao i ostalih dostupnih izvora (institucija, pojedinaca ili skupina). Ponuđene su i brojne nove usluge da bi korisnici mogli i nadalje koristiti knjižnične službe i usluge. Knjižnice su potaknule na aktivnost i samu zajednicu, koja je prepoznala vrijednost i zalaganje knjižničara, uključujući se više nego ikad u programe knjižnica.

Neki od problema uočenih u prethodnim istraživanjima o knjižnicama i njihovu korištenju društvenih mreža i dalje su aktualni. Primjerice, knjižnice nemaju dovoljno razrađenu viziju korištenja društvenih mreža i često se ograničavaju na održavanje samo jedne, administratori društvenih mreža nisu educirani te je potencijal društvenih mreža nedovoljno iskorišten. Objavljivanje često nije dosljedno i redovito, a većinu sadržaja na mrežu postavlja manji broj knjižnica, kao što je pokazalo i ovo istraživanje - $22 \%$ knjižnica objavilo je $53 \%$ sadržaja. No, unatoč svim tim problemima, možemo zaključiti da su knjižnice napravile važan pomak od djelitelja osnovnih informacija postale su stvaratelji raznovrsnog i kvalitetnog sadržaja kojim su potakle zajednicu na veće uključivanje u svoje virtualne živote. 


\section{LITERATURA}

Benčec, M. Hrvatske knjižnice na društvenoj mreži Facebook: diplomski rad. Zagreb: Filozofski fakultet, 2011. [citirano: 2020-12-14]. Dostupno na: http://darhiv.ffzg. unizg.hr/4243/1/1064BIBL.pdf.

Bradley, P. Social media for creative libraries. 2nd ed. London: Facet Publishing, 2015.

COVID-19 - Priopćenje prvog slučaja. // Hrvatski zavod za javno zdravstvo. [citirano: 2020-12-14]. Dostupno na: https://www.hzjz.hr/priopcenja-mediji/covid-19-priopcenje-prvog-slucaja/.

Dopuna IFLA-inog Manifesta. // IFLA-ine smjernice za narodne knjižnice / ur. Christie Koontz i Barbara Gubbin. 2. hrvatsko izd. Zagreb: Hrvatsko knjižničarsko društvo, 2011. Str. 118-119.

Facebook users by country 2020. // World Population Review. [citirano: 2020-1214]. Dostupno na: https://worldpopulationreview.com/country-rankings/facebook-users-by-country.

Hebrang Grgić, I. Facebook knjižničar: umijeće komuniciranja na društvenim mrežama. // Slobodan pristup informacijama: 12. okrugli stol / ur. Ana Barbarić, Dorja Mučnjak. Zagreb: Hrvatsko knjižničarsko društvo, 2013. Str. 33-46.

Hebrang Grgić, I. Knjižnice i knjižničari na Facebooku: kako iskoristiti prednosti i izbjeći zamke? // Svezak: časopis Društva knjižničara Bilogore, Podravine i Kalničkog prigorja 15(2013), 8-11.

Hebrang Grgić, I.; D. Mučnjak. Social networking phenomenon and its use in libraries. // Croatian Journal of Education 17, 1(2015), 217-241.

Holcer, D. Hrvatske narodne knjižnice i društvene mreže: doktorski rad. Zagreb: Filozofski fakultet, 2015. [citirano: 2020-12-14]. Dostupno na: http://darhiv.ffzg.unizg. $\mathrm{hr} / 5713 / 1 /$ Dunja_Holcer_Doktorski_rad.pdf

IFLA-in i UNESCO-ov Manifest za narodne knjižnice. // IFLA-ine smjernice za narodne knjižnice / ur. Christie Koontz i Barbara Gubbin. 2. hrvatsko izd. Zagreb: Hrvatsko knjižničarsko društvo, 2011. Str. 105-107.

IFLA-ine smjernice za narodne knjižnice / ur. Christie Koontz i Barbara Gubbin. 2. hrvatsko izd. Zagreb: Hrvatsko knjižničarsko društvo, 2011.

Majcen Linn, O. Prisutnost hrvatskih knjižnica na društvenoj mreži Facebook u razdoblju od 2012.- 2014.: diplomski rad. Zagreb: Filozofski fakultet, 2014. [citirano: 2020-12-14]. Dostupno na: http://darhiv.ffzg.unizg.hr/id/eprint/5006/.

Moja najdraža knjiga - sudjelujte i vi!. // Facebook stranica Gradske knjižnice Solin Teatrin. [citirano: 2020-12-14]. Dostupno na: https://www.facebook.com/ events/2618937985046612/.

Mučnjak, D.; I. Hebrang Grgić. Croatian and Irish public libraries on Facebook. // Qualitative and Quantitative Methods in Libraries 3(2012), 267-275. [citirano: 2020-12- 
14]. Dostupno na: http://www.qqml.net/papers/December_2012_Issue/5QQML_Journal_2012_Hebrang_Grgic-Mucnjak_3_267-275.pdf.

Mučnjak, D.; I. Hebrang Grgić. Libraries and librarians on Facebook: professional vs personal involvement. // Proceedings of the IADIS international conference: Web Based Communities and Social Media 2012: Collaborative technologies 2012 / Piet Kommers, Pedro Isaias, Nik Bessis (ed.). Lisbon: International Association for Development of the Information Society, 2012. Str. 160-164.

Nagradna igra „Otkrij naslov svog krimića“. // Facebook stranica Knjižnice i čitaonice Glina. [citirano: 2020-12-14]. Dostupno na: https://www.facebook.com/ events/657315438162967/).

Noć knjige. [citirano: 2020-12-14]. Dostupno na: https://nocknjige.hr/.

Pažur Vojvodić, I. Hrvatske knjižnice na društvenoj mreži Facebook. // 13. seminar Arhivi, knjižnice, muzeji: mogućnosti suradnje u okruženju globalne informacijske infrastrukture / Mirna Willer i Sanjica Faletar Tanacković (ur.). Zagreb: Hrvatsko knjižničarsko društvo, 2010. Str. 260-277.

Pšenica D.; B. Šalamon-Cindori; D. Vlahov. Novi oblici komunikacije knjižnica u online okruženju. // Slobodan pristup informacijama: 12. okrugli stol: zbornik radova. Zagreb: Hrvatsko knjižničarsko društvo, 2013. Str. 24-32.

Smjernice za knjižnične usluge za mladež: prerađeno izdanje Smjernica koje je 1996. objavio Stalni odbor Sekcije knjižnica za djecu i mladež / prir. Pat Muller i Ivan Chew; Web 2.0 i knjižnične usluge za mladež: uvod za knjižničare / prir. Ivan Chew. Zagreb: Hrvatsko knjižničarsko društvo, 2009.

Statistički podaci i pokazatelji uspješnosti za 2019. [citirano: 2020-12-14]. Dostupno na: http://maticna.nsk.hr/statistika/preuzimanje/.

Stožer civilne zaštite Republike Hrvatske. Odluka o mjerama ograničavanja društvenih okupljanja, rada u trgovini, uslužnih djelatnosti i održavanja sportskih i kulturnih događanja. [citirano: 2020-12-14]. Dostupno na: https://civilna-zastita.gov.hr/UserDocsImages/CIVILNA\%20ZA\%C5\%A0TITA/PDF_ZA\%20WEB/Odluka\%20 -\%20mjere\%20ograni\%C4\%8Davanja\%20dru\%C5\%A1tvenih\%20okupljanja, $\% 20$ rada\%20trgovina.pdf.

Stropnik, A. Knjižnica za nove generacije: virtualni sadržaji i usluge za mlade. Zagreb: Hrvatsko knjižničarsko društvo, 2013.

Virtualna radionica izrade uveza knjige „Knjige imaju svoju sudbinu“. // Facebook stranica Gradske knjižnice „Ivan Goran Kovačić“"Karlovac. [citirano: 2020-12-14]. Dostupno na: https://www.facebook.com/KnjiznicaKarlovac/posts/3745590642149582. 